\title{
Keragaman Parasitoid Erionota thrax l. pada Dua Jenis Tanaman Pisang Bermikoriza di Kabupaten Deli Serdang
}

\section{Diversity of Parasitoid Erionota thrax l. in Two Types of Mikoriza Banana in Deli Serdang}

\author{
Setiawan'), Maimunah $^{2}$ ), Suswati1) * \\ 1) Program Studi Agroteknologi, Fakultas Pertania, Universitas Medan Area, Indonesia
}

\begin{abstract}
Abstrak
Kendala dalam budidaya tanaman pisang adalah tingginya serangan hama yang merusak tanaman pada vase vegetatif. Penelitian dilaksanakan di Lahan Kelompok Tani Masyarakat Bersatu Desa Sampali Kecamatan Percut Sei Tuan Kabupaten Deli Serdang pada bulan Mei-Juli 2019. Metode penelitian yang digunakan adalah metode analisis deskriptif menggunakan sampel acak (random sampling). Parameter pengamatan terdiri dari kepadatan populasi, tingkat serangan hama, parasitoid telur, parasitoid larva, parasitoid pupa, identifikasi parasitoid, indeks keragaman jenis, indeks kemerataan jenis, dan kelimpahan relatif. Terdapat 4 jenis parasitoid yaitu Braconidae s 1 (Hymenoptera: Braconidae), Tachinidae sp 1 (Diptera: Tachinidae), Xanthopimpla gampsura (Hymenoptera: Ichneumonidae) dan Brachymeria lasus Walker (Hymenoptera: Chalcididae). Indeks keragaman parasitoid Erionota thrax L. 0,661369 dalam tingkat keanekaragaman rendah, dan kelimpahan relatif tertinggi Brachymeria lasus Walker 86,87 \%, tingkat serangan Erionota thrax pada pisang Barangan mencapai 46 \%, tingkat serangan Erionota thrax pada pisang Kepok mencapai $32 \%$.
\end{abstract}

Kata Kunci: Parasitoid Erionota thrax L, Dua Jenis Tanaman Pisang Bermikoriza

\begin{abstract}
The constraints in the cultivation of banana plants is the high number of pests that damage plants in vegetative vases. The study was conducted in the Farmers' Land Group of the United Society of Sampali Village, Percut Sei Tuan District, Deli Serdang Regency in May-July 2019. The research method used was descriptive analysis method using (random sampling). Observation parameters consisted of population density, pest attack rate, egg parasitoids, larva parasitoids, pupa parasitoids, parasitoids identification, species diversity index, species evenness index, and relative abundance. There are 4 types of parasitoids namely Braconidae sp 1 (Hymenoptera: Braconidae), Tachinidae sp 1 (Diptera: Tachinidae), Xanthopimpla gampsura (Hymenoptera: Ichneumonidae) and Brachymeria lasus Walker (Hymenoptera: Chalcididae). Erionota thrax L. parasitoids diversity index was 0.661369 in the low diversity level, and the highest relative abundance of Brachymeria lasus Walker was $86.87 \%$, the attack rate of Erionota thrax on Barangan bananas reached $46 \%$, the level of Erionota thrax on Kepok banana reached $32 \%$.

Keywords: Erionota thrax L. Parasitoid, Two Types of Bermikoriza Bananas.
\end{abstract}

How to Cite: Setiawan, Maimunah, \& Suswati, P. (2020). Keragaman parasitoid erionota thrax l. Pada dua Jenis tanaman pisang bermikoriza di kabupaten deli serdang, 6 (2): 106-111

*E-mail: setiwan21@gmail.com

ISSN 2550-1305 (Online)

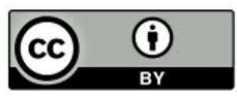


Setiawan, Maimunah \& Suswati, Keragaman parasitoid erionota thrax l. Pada dua Jenis tanaman pisang bermikoriza di kabupaten deli serdang

\section{PENDAHULUAN}

Produksi pisang di Indonesia didukung oleh berbagai faktor diantaranya, Indonesia merupakan salah satu sentra primer keragaman pisang. Lebih dari 200 jenis pisang terdapat di Indonesia, yang memberikan peluang untuk pemanfaatan dan komersialisasi pisang sesuai kebutuhan konsumen (Departemen Pertanian, 2005). Kemudian hampir semua jenis tanah di Indonesia cocok ditanami pisang. Indonesia yang tercatat sebagai negara produsen ranking keenam dunia, belum tercatat sebagai eksportir buah pisang. Sedangkan beberapa negara importir justru tercatat juga sebagai negara eksportir, contohnya yang menonjol dari negara-negara importir buah pisang yang juga menjadi eksportir adalah Belgia, Amerika Serikat, Jerman, dan Francis (Rusdiansyah, 2013).

Permintaan buah pisang cenderung meningkat setiap tahunnya, disebabkan karena, pisang memiliki gizi yang tinggi, harganya tergolong murah, tersedia bahan bakunya, tidak tergantung dengan musim, panen tidak tergantung waktu dan pisang memiliki gizi yang tinggi Buah pisang mengandung gizi cukup tinggi, kolesterol rendah serta vitamin B6 dan vitamin $C$ tinggi. Zat gizi terbesar pada buah pisang masak adalah kalium sebesar 373 miligram per 100 gram pisang, vitamin A 250-335 gram per 100 gram pisang dan klor sebesar 125 miligram per 100 gram pisang. Pisang juga merupakan sumber karbohidrat, vitaminn A dan C, serta mineral. Komponen karbohidrat terbesar pada buah pisang adalah pati pada daging buahnya, dan akan diubah menjadi sukrosa, glukosa dan fruktosa pada saat pisang matang (15-20\%) (Ismanto, 2015).

Pisang mempunyai potensi dan nilai ekonomis yang cukup tinggi jika diusahakan dengan baik. Menurut data dari Badan Pusat Statistik (2014), harga pisang di tingkat produsen cenderung terus meningkat dari tahun ke tahun. Rata-rata laju pertumbuhan harga pisang di tingkat produsen sebesar 13,96\% per tahun. Tahun 1993 harga pisang di tingkat produsen hanya sebesar Rp. 532,-/sisir, dan meningkat menjadi Rp. 5.638,-/sisir. Peningkatan harga yang cukup signifikan terjadi pada tahun 1993-2002 dengan pertumbuhan mencapai $24,17 \%$ per tahun. Setelah tahun 2002 peningkatan harga pisang di tingkat produsen hanya sebesar $4,77 \%$ per tahun. Sebaliknya, berbagai faktor dapat menyebabkan kemerosotan produksi pisang, antara lain budidaya yang kurang baik, serta gangguan hama dan penyakit.

Berdasarkan Badan Pusat Statistik (2015) data rata-rata produksi tahun 2009-2013, sebanyak 70,30\% produksi pisang Indonesia dipasok dari Provinsi Jawa Barat, Jawa Timur, Lampung, Jawa Tengah, dan Sumatera Utara. Jawa Barat memberikan kontribusi terbesar terhadap produksi pisang Indonesia, yaitu sebesar 20,03\%, diikuti oleh Jawa Timur (19,60\%), Lampung (12,38\%), Jawa Tengah (12,20\%), dan Sumatera Utara $(6,10 \%)$, sedangkan provinsi-provinsi lainnya memberikan kontribusi terhadap produksi pisang Indonesia kurang dari 5\%. Permintaan konsumen sangat tinggi terhadap pisang. Terlihat dari data BPS (2017), produksi pisang mengalami peningkatan dari tahun 2011 sampai 2015. Rataan produksi pisang per tahun di Indonesia adalah 6.55 juta ton. Produksi terendah terjadi pada tahun 2011 yaitu 6.13 juta ton dan produksi tertinggi terjadi pada tahun 2015 yaitu 7.3 juta ton. Produksi tersebut sebagian besar dipanen dari 
pertanaman kebun rakyat seluas 269000 ha. Menurut BPS ( 2016 ) Dinas Tanaman Pangan dan Hortikutura Provinsi Sumatera Utara produksi buah pisang sebesar 137.886 ton.

Produksi di tahun 2016 menurun dibandingkan dengan produksi tahun 2015. Hal ini dikarenakan adanya serangan hama yang dapat menurunkan produktivitas pisang di Indonesia terutama di Provinsi Sumatera Utara. Salah satu hama yang paling utama menyerang tanaman pisang adalah dari kelompok serangga yang dapat menurunkan produktivitas pisang adalah Erionota thrax L. Erionota thrax merupakan hama yang paling sering ditemukan keberadaannya dan menjadi hama utama dengan tingkat serangan tertinggi dibandingkan hama lainnya. Stadia yang merusak dari hama ini adalah stadia larva. Erionota thrax menyerang bagian daun pisang dan apabila dibiarkan tanaman akan menjadi gundul serta hanya tampak tulang daunnya. Larva ini begitu keluar dari telur akan memotong lamina daun mulai dari pinggir dan menggulungnya hingga akhirnya daun menjadi kering, sobek-sobek serta mengakibatkan tanaman mati bila dibiarkan terus menerus (Satuhu dan Supriyadi, 2007 dalam Yudi dkk, 2016).

Selama ini pengendalian Erionota thrax menggunakan insektisida kimia. Apabila dilakukan penggunaan bahan kimia secara terus menerus dalam jangka waktu yang lama, maka akan memiliki efek terhadap kematian dari musuh alami. Sehingga dalam hal ini perlu dilakukan tindakan dalam pengendalian Erionota thrax. Penggunaan insektisida memiliki dampak negatif yang akan menyebabkan matinya musuh alami, mengalami resistensi dan resusgensi. Maka perlu dilakukan pengendalian hayati pada hama Erionota Thrax L. Pengendalian hayati adalah pengendalian hama dengan memanfaatkan musuh alami yang berada di alam. Salah satu musuh alami yang dapat dimanfaatkan untuk mengendalikan hama adalah parasitoid. Parasitoid adalah serangga yang hidup menjadi parasit di dalam atau pada tubuh serangga lain, dan membunuhnya secara pelan-pelan (Direktorat Perlindungan Perkebunan, 2002). Peran musuh alami akan mengurangi siklus hidup dari Erionota Thrax L. Oleh karena itu penulis tertarik untuk meneliti, sehingga penulis tertarik untuk melakukan penelitian dengan judul "Keragaman Parasitoid Erionota Thrax L. Pada Dua Jenis Tanaman Pisang Bermikoriza Di Lahan Kelompok Tani Masyarakat Bersatu Desa Sampali Kecamatan Percut Sei Tuan Kabupaten Deli Serdang".

\section{METODE PENELITIAN \\ Pengumpulan Sampel}

Pengumpulan data dilakukan dengan cara pengamatan langsung di lapangan. Umur tanaman pisang yang dijadikan sebagai sampel berumur 13 bulan. Terdiri dari 2 blok, blok 1 pisang barangan dan blok 2 pisang kepok, pertanaman pisang diamati sebanyak $20 \%$ tanaman pisang dari total keseluruhan tanaman dalam satu blok. Sebelumnya dihitung tingkat kepadatan populasi dan intensitas serangan.

\section{Pengamatan masing-masing stadia pertumbuhan Erionota thrax L.}

Kelompok telur yang ditemukan dikumpulkan dan disimpan dalam wadah plastik kemudian dipelihara di laboratorium. Jumlah telur yang ditemukan pada setiap tanaman 
Setiawan, Maimunah \& Suswati, Keragaman parasitoid erionota thrax l. Pada dua Jenis tanaman pisang bermikoriza di kabupaten deli serdang

dikumpulkan. Setiap hari telur diamati untuk mengetahui apakah telur menetas atau timbul parasitoid. Parasitoid yang muncul diidentifikasi dan dihitung jumlahnya.

Larva yang ditemukan di lapangan dikumpulkan dan dipelihara di laboratorium dan diamati setiap hari untuk mengetahui keberadaan parasitoid. Parasitoid yang muncul diidentifikasi dan dihitung jumlahnya. Selanjutnya, Pupa yang ditemukan di lapangan dikumpulkan lalu disimpan dalam wadah plastik dan dipelihara di laboratorium dan dihitung Jumlah pupa yang ditemukan pada setiap tanaman. Parasitoid yang muncul diidentifikasi dan dihitung jumlahnya. Jumlah pupa yang terparasit dan yang tidak terparasit dihitung untuk mengetahui tingkat parasitisasinya. Parasitoid yang keluar dari telur, larva atau pupa dimasukkan ke dalam alcohol 70\%, kemudian dilakukan identifikasi dengan menggunakan kunci identifikasi serangga (Borror, Triplehorn, Johnson, 1996). Dalam melakukan identifikasi digunakan mikroskop cahaya. Parasitoid diidentifikasi sampai famili dan dikoleksi dalam bentuk koleksi kering dan basah.

\section{Analisis Statistika}

\section{Analisis Indeks Keragaman Jenis ( $\left.\mathrm{H}^{\prime}\right)$}

Analisis data berupa indeks keanekaragaman Shannon-Wiener ( $\left.\mathrm{H}^{\prime}\right)$ menurut (Magurran, 1988). Indeks kemerataan Jenis Struktur komunitas dengan menghitung nilai indeks kemerataan antar jenis atau indeks Evennes (E) (Magurran, 1988) sebagai berikut

Struktur komunitas dengan menghitung nilai indeks kemerataan antar jenis atau indeks Evennes (E) (Magurran, 1988) sebagai berikut :

$$
\mathrm{E}=\frac{\mathrm{H}^{\prime}}{\ln (\mathrm{S})}
$$

Keterangan :

E : Indeks kemerataan jenis

$\mathrm{H}^{\prime} \quad$ : Indeks Shannon

S : Jumlah jenis yang ditemukan ln

In : Logaritma natural

\begin{tabular}{cl}
\hline Nilai tolak ukur & \multicolumn{1}{c}{ Keterangan } \\
\hline $\mathrm{H}^{\prime}<1,0$ & $\begin{array}{l}\text { Keanekaragaman rendah, } \\
\text { miskin, produktivitas sangat } \\
\text { rendah sebagai indikasi adanya } \\
\text { tekanan yang berat dan } \\
\text { ekosistem tidak stabil }\end{array}$ \\
& $\begin{array}{l}\text { Keanekaragaman sedang, } \\
\text { produktivitas cukup, kondisi } \\
\text { ekosistem cukup seimbang, } \\
\text { tekanan ekologis sedang. }\end{array}$ \\
& $\begin{array}{l}\text { Keanekaragaman tinggi, } \\
\text { stabilitas ekosistem mantap, } \\
\text { produktivitas tinggi, tahan } \\
\text { terhadap tekanan ekologis. }\end{array}$ \\
\hline
\end{tabular}


Kemerataan jenis memiliki nilai indikator $\mathrm{E}=1$. Apabila nilai $\mathrm{E}=1$ berarti pada habitat tersebut tidak ada jenis yang mendominasi. Rumus kelimpahan relatif (KR) menurut Odum \& Barrett (2005).

\section{HASIL DAN PEMBAHASAN}

Kepadatan Populasi Erionata thrax L. Pada Pisang Barangan

Kepadatan populasi hama ulat penggulung daun pisang yang terjadi di lahan Kelompok Tani Masyarakat Bersatu Desa Sampali Kecamatan Percut Sei Tuan dapat disajikan pada tabel 1 .

Tabel 2. Kepadatan Populasi Erionota thrax Pada Tanaman Pisang Barangan Bermikoriza Pada Minggu 1 Minggu 6

\begin{tabular}{cccc}
\hline Minggu ke- & Jumlah Tanaman & Erionota thrax & KP* \\
\hline 1 & 80 & 171 & 2.14 \\
2 & 80 & 246 & 3.08 \\
3 & 80 & 211 & 2.64 \\
4 & 80 & 169 & 2.11 \\
5 & 80 & 141 & 1.76
\end{tabular}

6801602.00

$* \mathrm{KP}=$ Kepadatan Populasi

Berdasarkan tabel 2 menunjukkan bahwa kepadatan populasi hama ulat penggulung daun pisang (Erionata thrax L.) pada tanaman pisang barangan bermikoriza dengan sampel tanaman yang diamati 80 rumpun pisang. Kepadatan populasi tertinggi terjadi pada minggu ke 2 yaitu 3.08 dengan jumlah ulat penggulung daun pisang sebanyak 246 ekor. Sedangkan kepadatan populasi terendah terjadi di minggu ke 5 yaitu 1, 76 dengan jumlah ulat penggulung daun pisang sebanyak 141 ekor. Sedangkan pada minggu ke 1, 3, 4 dan 6 kondisi kepadatan populasi netral.

\section{Kepadatan Populasi Erionata thrax L Pada Pisang Kepok}

kepadatan populasi hama ulat penggulung daun pisang (Erionata thrax L.) pada tanaman pisang kepok bermikoriza dengan sampel tanaman yang diamati 54 rumpun pisang. Kepadatan populasi tertinggi terjadi pada minggu ke 2 yaitu 3.20 dengan jumlah ulat penggulung daun pisang sebanyak 173 ekor. Sedangkan kepadatan populasi terendah terjadi di minggu ke 5 yaitu 1,20 dengan jumlah ulat penggulung daun pisang sebanyak 65 ekor. Sedangkan pada minggu ke 1, 3, 4 dan 6 kondisi kepadatan populasi netral.

\section{Analisis Erionata thrax $L$ Pada Setiap Stadia Perkembangan}

Gejala serangan E. thrax pada tanaman pisang barangan dan kepok menunjukkan adanya gejala dibagian tepi daun yang menggulung. Pada saat di lapangan banyak ditemukan gulungan yang berukuran kecil sedang sampai yang paling besar (Gambar 7b), berisi larva yang berukuran kecil $(<4 \mathrm{~cm})$. Tingkat serangan Erionota thrax pada tanaman pisang barangan diketahui luas serangannya mencapai $46 \%$ dari total tanaman pisang barangan 560 tanaman, sehingga ada 258 tanaman yang terserang hama Erionota thrax. 
Setiawan, Maimunah \& Suswati, Keragaman parasitoid erionota thrax l. Pada dua Jenis tanaman pisang bermikoriza di kabupaten deli serdang

Sedangkan pada tanaman pisang kepok diketahui luas serangannya mencapai $32 \%$ dari total tanaman pisang kepok sebanyak 257 tanaman, sehingga ada 83 tanaman yang terserang Erionota thrax. Serangan E. thrax ditemukan di jenis pisang barangan pengamatan dengan tingkat serangan yang berbeda-beda. Jumlah gulungan dalam satu daun bervariasi antara 0 sampai 20 gulungan.
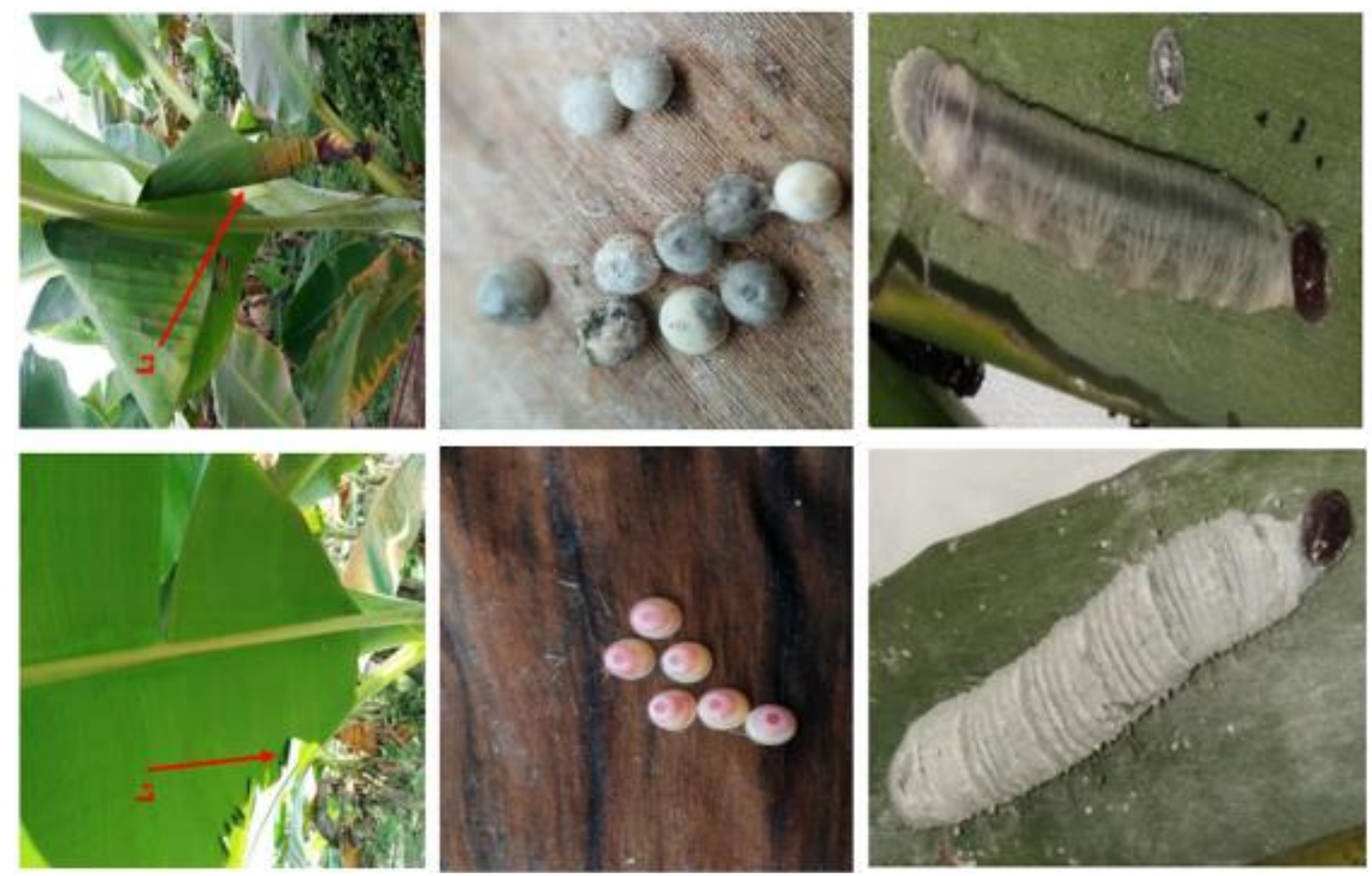

Gambar 1. Perkembangan Erionata thrax L. Pada setiap stadia perkembangannya

Telur yang berwarna kuning kemerahan menandakan tidak terparasit atau telur yang masih sehat, sedangkan telur yang berwarna putih kehitaman biasanya terparasit, ada juga telur yang diselimuti bulu halus kecil yang menandakan telur terserang patogen. Telur akan diketahui terparasit atau tidak setelah telur dipelihara di laboratorium dan menetas menjadi larva atau muncul parasitoid (Novianti, 2008). Telur E. thrax ditemukan di lapangan pada saat pengamatan yang jumlahnya bervariasi dan berkelompok, dapat ditemukan di permukaan daun muda maupun daun tua.

Telur E. thrax ditemukan pada permukaan atas dan permukaan bawah daun. Telur E. thrax memiliki bentuk yang unik yaitu berbentuk seperti kuba, dan diatasnya terdapat lingkaran kecil berwarna merah, dibagian keseluruhan telur terdapat garis liris menjulang keatas. Telur yang berwarna kuning kemerahan menandakan tidak terparasit atau telur yang masih sehat, sedangkan telur yang berwarna putih kehitaman biasanya terparasit, ada juga telur yang diselimuti bulu halus kecil yang menandakan telur terserang patogen. Telur akan diketahui terparasit atau tidak setelah telur dipelihara di laboratorium dan menetas menjadi larva atau muncul parasitoid (Novianti, 2008). Telur E. thrax ditemukan di lapangan pada saat pengamatan yang jumlahnya bervariasi dan berkelompok, dapat ditemukan di permukaan daun muda maupun daun tua. 
Parasitoid larva yang muncul terdiri dari 2 spesies yaitu 1 spesies berasal dari Ordo Hymenoptera dan 1 spesies berasal dari Ordo Diptera (Tabel 1). Hymenoptera spesies pertama tergolong dalam famili Braconidae dengan ciri-ciri panjang tubuh $0,3 \mathrm{~cm}$, berwarna hitam, ovipositor pendek, antena tipe filiform berbentuk melengkung. Larva yang terparasit oleh Braconidae ini biasanya dicirikan oleh adanya kokon berwarna putih di sekitar bagian tubuh. Larva yang terparasit oleh Braconidae biasanya masih hidup kemudian baru mati Gambar 2.

Table 1. Keragaman Parasitoid Erionota thrax L.Pada Dua Jenis Tanaman Pisang Bermikoriza Stadia Larva

\begin{tabular}{clll}
\hline NO & Ordo & Family & \multicolumn{1}{c}{ Spesies } \\
\hline $\mathbf{1}$ & Hymenoptera & Braconidae & Braconidae Sp. \\
$\mathbf{2}$ & Diptera & Tachinidae & Tachinidae Sp 1 \\
\hline
\end{tabular}

Kepadatan populasi hama ulat penggulung daun pisang (Erionata thrax L.) pada tanaman pisang kepok bermikoriza dengan sampel tanaman yang diamati 54 rumpun pisang. Kepadatan populasi tertinggi terjadi pada minggu ke 2 yaitu 3.20 dengan jumlah ulat penggulung daun pisang sebanyak 173 ekor. Sedangkan kepadatan populasi terendah terjadi di minggu ke 5 yaitu 1,20 dengan jumlah ulat penggulung daun pisang sebanyak 65 ekor. Sedangkan pada minggu ke 1, 3, 4 dan 6 kondisi kepadatan populasi netral.

Parasitoid pupa yang sudah dipelihara, ditemukan ada 2 jenis spesies yang berbeda yang tergolong kedalam family Ichneumonidae dan Chalcididae. Ciri dari family Ichneumonidae tubuh yang besar dan lonjong, mempunyai antena yang panjang dengan,

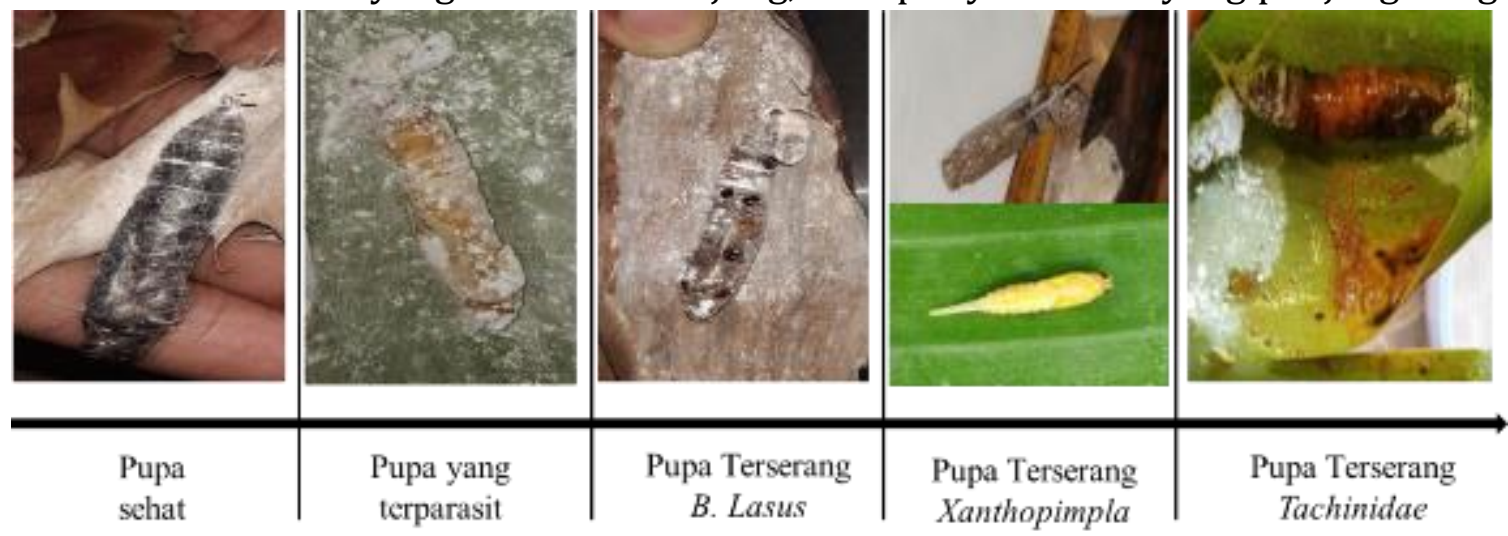

Gambar 2. Perbedaan Pupa yang sehat dan Terparasit (a) Pupa E. thrax yang sehat; (b) Pupa E. thrax yang terparasit; (c) Gejala pupa yang terserang Bracymeria lasus; (d) Gejala pupa yang terserang Xanthopimpla; (e) Gejala Pupa yang terserang Family Tachinidae

memiliki abdomen yang runcing dibagian ujungnya dan ovipositor panjang. Famili Ichneumonidae ini juga dapat diketahui dari warnanya yaitu berwarna kuning dan memiliki kaki yang panjang. Hal ini sependapat dengan (Novianti, 2008) menyatakan bahwa famili Ichneumonidae memiliki ciri-ciri tubuh yang besar dengan ukuran sekitar 10 - $14 \mathrm{~mm}$, mempunyai antena yang panjang dengan 16 ruas, dan ovipositor panjang. Famili Ichneumonidae ini juga dapat diketahui dari warna, ukuran, bentuk tubuh dan sayapnya. Parasitoid dari famili Ichneumonidae yang ditemukan ada tiga spesies yaitu Charops sp., Casinaria sp., dan Xanthopimpla sp., ketiganya bersifat parasitoid soliter. Pada 
Setiawan, Maimunah \& Suswati, Keragaman parasitoid erionota thrax l. Pada dua Jenis tanaman pisang bermikoriza di kabupaten deli serdang

umumnya Famili Ichneumonidae memiliki ciri yaitu ukuran tubuhnya berkisar $13 \mathrm{~mm}$, berwarna hitam, antenanya panjang berjumlah 16 ruas (Wibowo, 2015). Spesies kedua tergolong dalam famili Chalcididae dengan ciri-ciri tubuh yang berukuran panjang $0,5 \mathrm{~cm}$, tubuh berwarna hitam, sayap yang tipis dan kaki berwarna kuning. Famili Ichneumonidae ini juga dapat diketahui dari warna, ukuran, bentuk tubuh dan sayapnya. Spesies kedua tergolong dalam famili Chalcididae dengan ciri-ciri tubuh yang berukuran panjang $5 \mathrm{~mm}$, femur belakang menggembung dan bergeligi, berwarna hitam dengan tanda berwarna kuning (Novianti, 2008).

\section{SIMPULAN}

Tingkat serangan Erionota thrax pada tanaman pisang barangan mencapai $46 \%$. Tingkat serangan Erionota thrax pada tanaman pisang kepok mencapai $32 \%$. Terdapat 4 Spesies Serangga pada tanaman pisang barangan dan kepok bermikoriza yaitu Braconidae sp 1 (Hymenoptera: Braconidae), Tachinidae sp (Diptera: Tachinidae), Xanthopimpla gampsura (Hymenoptera: Ichneumonidae) dan Brachymeria lasus Walker (Hymenoptera: Chalcididae). Musuh alami pisang barangan dan kepok stadia larva yaitu Braconidae sp 1 dan Tachinidae sp 1. Musuh alami stadia pupa yaitu Xanthopimpla gampsura dan Brachymeria lasus.

\section{DAFTAR PUSTAKA}

BPS. (2016). Produksi Buah-buahan tahun 2016. Dinas Tanaman Pangan dan Hortikultura Provinsi Sumatera Utara

Badan Pusat Statistik. (2014). Potret Usaha Pertanian Indonesia Menurut Sub Sektor.Jakarta: Badan Pusat Statistik.

Badan Pusat Statstik. (2015) Produksi Tanaman Pisang Seluruh Provinsi. Diakses dari www.bps.go.id pada tanggal 22 Januari 2019.

Badan Pusat Statstik. (2017). Produksi Pisang Di Indonesia. Diakses dari www.bps.go.id pada tanggal 08 Maret 2019.

Departemen Pertanian. (2005). Prospek dan Arah Pengembangan Agribisnis Pisang.Jakarta: Badan Penelitian Dan Pengembangan Pertanian DepartemenPertanian.

Direktorat Perlindungan Perkebunan \& Direktorat Jenderal Bina Produksi Perkebunan Departemen Pertanian. (2002). Musuh Alami, Hama danPenyakit Tanaman Lada. Proyek Pengendalian Hama Terpadu Perkebunan Rakyat. Jakarta.

Erniwati \& Ubaidillah R. (2011). Hymenopteran parasitoids associated with the banana-skipper Erionota thrax L. (Insecta: Lepidoptera, Hesperiidae) in Java, Indonesia. Biodiversitas 12(2): 76-85.

Goulet H \& Huber JT. (1993). Hymenoptera of the World: An Identification Guide to Families. Canada Communication Group. Ottawa, Canada.

Borror DJ, Triplehorn CA, \& Johnson NJ. (1992). Pengenalan pelajaran serangga: Gadjah Mada University.

Ismanto H. (2015). Pengolahan Tanpa Limbah Tanaman Pisang. Laboratorium Pengolahan Hasil Pertanian. Balai Besar Pelatihan Pertanian. Batangkaluku.

Magurran AE. (2013). Measuring biological diversity: John Wiley \& Sons.

Novianti F. (2008). Hama Penggulung Daun Pisang Erionota Thrax Linnaeus (Lepidoptera: Hesperidae) dan Musuh Alaminya di Tempat-Tempat dengan Ketinggian Berbeda. Fakultas Pertanian. IPB. Bogor.

Odum E.P., \& Barrett, G.W. 2005. Fundamental of Ecology. Fifth Edition.Belmont, USA. Thomas Brooks/Cole. 598 hal.

Rusdiansyah D. (2013). Potensi dan Peluang Investasi serta Permasalahan Komoditi Pisang di Kalimantan Timur. Badan Perijinan Penanaman Modal Daerah Provinsi Kalimantan Timur.

Satuhu S, \& Supriyadi A. (1992). Pisang: budidaya, pengolahan, dan prospek pasar: Penebar Swadaya.

Wibowo L. (2015). Kemelimpahan Dan Keragaman Jenis Parasitoid Hama Penggulung Daun Pisang Erionota Thrax L. Di Kabupaten Lampung Selatan. Jurnal Hama dan Penyakit Tumbuhan Tropika, 15(1), 26-32. 